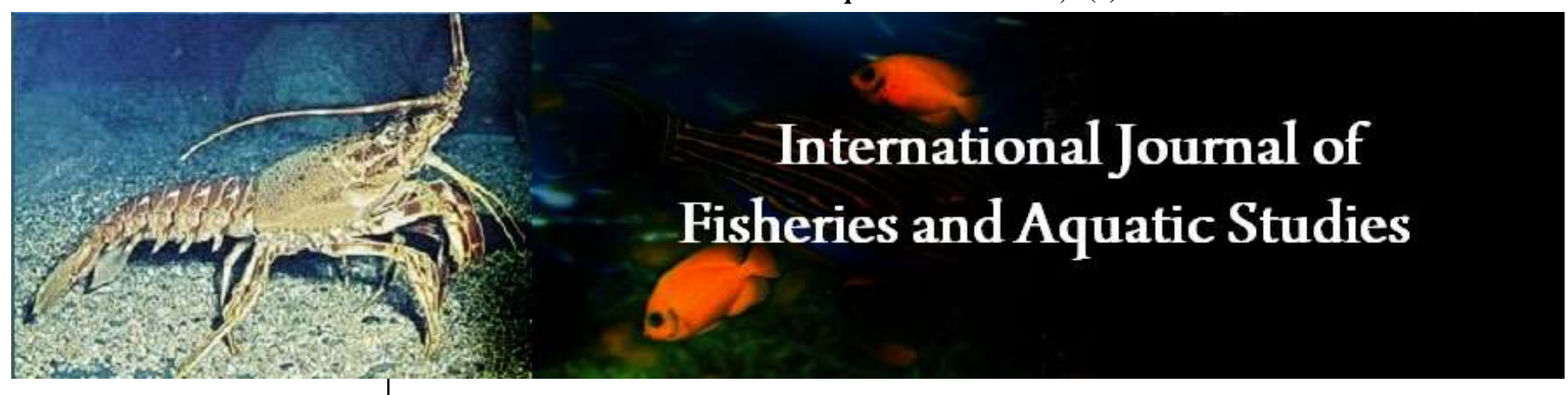

E-ISSN: 2347-5129

P-ISSN: 2394-0506

(ICV-Poland) Impact Value: 5.62

(GIF) Impact Factor: 0.549

IJFAS 2021; 9(1): 131-134

(C) 2021 IJFAS

www.fisheriesjournal.com

Received: 11-11-2020

Accepted: 17-12-2020

Fittrie Meyllianawaty Pratiwy

Department of Fisheries, Faculty of Fisheries and Marine Science,

Universitas Padjadjaran, Jl.

Raya Sumedang KM 21

Sumedang, Indonesia

\section{Roffi Grandiosa}

Department of Fisheries, Faculty of Fisheries and Marine Science,

Universitas Padjadjaran, Jl.

Raya Sumedang KM 21

Sumedang, Indonesia

Fajar Nurul Arifah

Student of Faculty of Fisheries and Marine Science, Universitas Padjadjaran, Jl. Raya Sumedang KM 21 Sumedang, Indonesia

Corresponding Author: Fittrie Meyllianawaty Pratiwy Department of Fisheries, Faculty of Fisheries and Marine Science, Universitas Padjadjaran, Jl. Raya Sumedang KM 21 Sumedang, Indonesia

\section{The enrichment of live feeds: An inquiry for feeding at early stages of fish}

\author{
Fittrie Meyllianawaty Pratiwy, Roffi Grandiosa and Fajar Nurul Arifah
}

DOI: $\underline{\text { https://doi.org/10.22271/fish.2021.v9.i1b.2394 }}$

\begin{abstract}
Artemia and daphnia are well known as the most suitable live feeds for larviculture. The appropriate size, easy digest, and high nutritional value are the main criteria to choose as a live feed in early stage of fish. Some of essential fatty acids are low in this species and the enrichment is one of other ways to improve the fatty acids. Thus, it can be the appropriate feed to fulfill the nutritional requirement of larvae. Mostly, enrichment have been done using the source of high content of lipid such as oil enrichment, the dose 2-3 $\mathrm{ml} / \mathrm{l}$ of oil source enrichment could give a positive impact to the nutritional value of larva, increase the survival rate, and boost the growth performance. Recently, the utilities of live feeds facing the reality of sustainable issues such as the availability of pure strain, pathogen free, and the high maintenance of environmental condition. It could be the major limit for small-scale industry to ensure the quality and sustainability of live feeds. Many studies have been carried out to magnificent this problems. This paper discuss about the various enrichments for the most used live feeds in larviculture, such as Artemia, Moina, Daphnia, and Infusoria. The proximate analysis also become the additional information such as the increasing of protein contents in higher dose of enrichment.
\end{abstract}

Keywords: Live feeds, enrichments, lipid enrichment, artemia, daphnia, moina, infusoria

\section{Introduction}

The natural feed can be defined as derived feed from nature. Due to the uncertain availability of feed in nature, feed mostly cultivated by humans to ensure a sustainable supply ${ }^{[1]}$. Live feed such as microalgae ${ }^{[2]}$; phytoplankton and zooplankton ${ }^{[3]}$ become the main natural feeds for aquaculture. There are several criteria used to select the organism as a natural feed in aquaculture, such as size and density during feeding, nutritional value, and pathogen free [3]. Size and density during feeding affect the digestion and absorption by the fish body. Nutritional value also affect the growth performance and welfare of the fish. The pathogen free indicated the low risk disease caused by the live feed as a vector.

Mostly, Rotifers and Artemia are being use as live feeds ${ }^{[4]}$. They are well known as the most forthright live feed to mass culture ${ }^{[5]}$. Ciliates and infusoria also used as natural feeds especially in the early stage of life due to its high nutritional content ${ }^{[6]}$.

Enrichment describes feeding live feeds on other feeds to improve their nutritional value ${ }^{[5]}$. Artemia mostly enriched to increase the essential fatty acids because DHA and carotenoid concentrations are originally low in this species Thus, it usually enriched with nutrient containing lipid and any other DHA sources. Enrichment with amino acids, nucleotides, minerals, pigments and other nutrients also is being studied ${ }^{[5]}$. Thus, these feed organisms are usually enriched with material containing lipids and any other DHA sources, such as lipid contents and algae ${ }^{[7]}$.

To examine dietetic value of live feeds, a proximate analysis can be supported as a chemical content test. This review is discussing about the nutritional content in live feeds after being enriched and its advantages in aquaculture system especially to fulfill the nutritional requirement in early stage of fish.

\section{The enrichment in Moina and daphnia culture}

The Moina sp. and Daphnia sp. are freshwater cladoceran with high content of protein and other nutrients ${ }^{[8]}$. However, similar with Artemia, the fatty acids content does not meet the requirement for fish and crustacean larvae feed ${ }^{[9]}$. Thus, the enrichment of those species culture for live feed of fish is needed. 
The culture of Moina and Daphnia mostly have been done in hatchery to produce the stable large quantities. Several research have been done dealing with the enrichment method for Moina such as enriched with lipids from inexpensive squid of canola oil. The results showed that Arachidonic acid (AA) significantly increased from $<0.01$ to $0.38 \mathrm{mg} / \mathrm{g}$ in Moina enriched in $2 \mathrm{~g} / \mathrm{l}$ canola oil for $12 \mathrm{~h}^{[10]}$. The enriched Moina could increase the performance of fish. Such as in catfish ${ }^{[11]}$, the enrichment of Moina sp. with fish meal with dose $6 \mathrm{~g} / 1$ could increase the survival rate of catfish larvae. However, it is not recommended to give fish meal excessively because it can contaminate the media and can increase the mortality in Moina sp. The proximate analysis showed with higher dose resulted higher nutritional value and dose of $6 \mathrm{~g} / \mathrm{l}$ fishmeal enrichment showed an increasing in fat content of $0.77 \%$, fiber $0.77 \%$ and protein $5.07 \%$. As for the ash content of $1.23 \%, 90.46 \%$ water and $1.67 \%$ crude fiber (Table 1 ). In addition, this dose showed the highest percentage for survival of fish larvae at $98 \%$, and growth in length of fish larvae by $2.3 \mathrm{~cm}$.

On the other hand, the enrichment of daphnia has been done using Spirulina platensis meal ${ }^{[12]}$ with different doses on the growth and survival of goldfish larvae. The highest protein content of $5.40 \%$ was found in the treatment with dose of 7 gr/l. The higher dose of Spirulina platensis, the higher increasing of protein content in Daphnia. The following is the nutritional content of enriched water fleas, $5.40 \%$ crude protein, $0.81 \%$ fat, $92.97 \%$ moisture, $0.18 \%$ ash and $0.59 \%$ crude fiber (Table 1). Furthermore, the application of daphnia enriched with Spirulina platensis meal showed a significant effect $(P<0.05)$ on growth performance of Goldfish. The fatty acid contain in Moina and Daphnia is strongly influenced by the lipid ratio of the enrichment contents. Other sources of fatty acid, either animal or plant-based oil emulsions with high content of fatty acids.

\section{The enrichment in Artemia culture}

The successfully rearing period in early stage of fish lifespan mostly depends on the availability of feed and good nutritional value. Commonly, most of fish farm using Artemia during this critical period. Nevertheless, Artemia is not suitable for marine fish larvae since they are mainly deficient in essential Hufa [13], especially a deficient in eicosapantaenoic acid (EPA; 20:5n-3) and doccosahexanoic acid (DHA; 22:6n-3) ${ }^{[14]}$.

Improvements in live feed nutrition is necessary to solve this problem such as enrichment. Several studies have been demonstrated the positive effect of enriched live food on the growth and survival performance of various aquaculture species. The live feed Artemia nauplii with highly unsaturated fatty acid (HUFA) + vitamin C enriched were tested to trout larva culture showed the highest percentage of survival (96\%) of trout larvae $(P<0.05)$. In addition, the body composition of trout after one week feeding showed that the protein in the larvae fed by Artemia nauplii enriched was significantly different compared to unenriched $(P<0.05)^{[15]}$. High protein level in live feed with enrichment can fulfill the dietary protein need in larvae culture, especially to help the fast growth rate. Furthermore, Artemia contain the proteolytic enzymes may help a significant contribution to digestion process ${ }^{[16]}$. The comparison fatty acid contents between enriched and unenriched Artemia are shown in Table 1.

Table 1: Fatty acid composition (\% total fatty acids) of the various enrichments for Artemia culture

\begin{tabular}{|c|c|c|c|c|}
\hline $\begin{array}{c}\text { Fatty } \\
\text { acid }\end{array}$ & $\begin{array}{c}\text { Artemia without } \\
\text { Enrichment }^{[15]}\end{array}$ & $\begin{array}{c}\text { Artemia enriched with } \\
\text { HUFA+Vitamin C }^{[15]}\end{array}$ & $\begin{array}{c}\text { Artemia enriched with } \\
\text { lipid emulsion }^{[17]}\end{array}$ & $\begin{array}{c}\text { Artemia enriched with } \\
\text { emulsified } \boldsymbol{O} \text {. niger liver oil }^{[18]}\end{array}$ \\
\hline $14: 0$ & $1.30 \pm 0.10$ & $1.30 \pm 0.20$ & 0.1 & 1.14 \\
\hline $16: 0$ & $15.79 \pm 0.39$ & $15.50 \pm 1.95$ & 0.9 & 8.43 \\
\hline $18: 0$ & $3.99 \pm 0.78$ & $4.53 \pm 0.07$ & N/A & N/A \\
\hline $18: 1 \mathrm{n}-9$ & $18.35 \pm 0.47$ & $16.67 \pm 0.43$ & 3.7 & 10.14 \\
\hline $18: 2 \mathrm{n}-6$ & $10.12 \pm 1.95$ & $11.33 \pm 0.54$ & 0.7 & 22.9 \\
\hline $18: 3 \mathrm{n}-3$ & $30.48 \pm 1.83$ & $36.43 \pm 0.37$ & 0.6 & 5.1 \\
\hline $20: 5 \mathrm{n}-3$ & $2.80 \pm 0.43$ & $7.72 \pm 0.32$ & 7.7 & 44.18 \\
\hline PUFA & $27.18 \pm 1.84$ & $43.42 \pm 3.5$ & 91.1 & N/A \\
\hline HUFA & $2.80 \pm 0.43$ & $8.99 \pm 0.28$ & 8.0 & \\
\hline
\end{tabular}

*PUFA=poly unsaturated fatty acid; HUFA= highly unsaturated fatty acid

The Artemia-enriched using bio floc could increase the body weight of shrimp larva with daily growth was daily growth was $1.4 \mathrm{mg} /$ day and for survival rates was $99 \%{ }^{[19]}$. Other source of enrichment is diatom cells ${ }^{[20]}$, Artemia enriched with diatom cells could increase the growth performance of vannamei shrimp.

\section{The enrichment in infusoria culture}

In term of definition, infusoria is refers to several phyla of the Protozoa group. Protozoa itself is defined as a group of organisms eukaryotic unicellular, free-living or parasitic, and feed on material organic matter such as microorganisms, organic wipes and flakes ${ }^{[21]}$. Nowadays, the term infusoria is being transformed to a single phylum, namely Ciliophora. Ciliophora is a group of Protozoa characterized by cilia organelles. These organelles are structurally identical to the eukaryotic flagellates, but shorter and has a larger number of flagella.

Infusoria has a small, soft, and high nutrition so it is suitable to use as natural food for fish larvae at an early stage. Infusoria is frequently used as the only source of nutrition, either in marine waters or in freshwater during the early development of fish, the stage before fish larvae starting consume copepods ${ }^{[6,22]}$ and become the promising candidates for mass production ${ }^{[5]}$. Further, some studies have been revealed to increase the production of cultivated infusoria, such as by enrichment.

The research conducted regarding the growth rate and density of infusoria using mackerel tuna (Euthynnus affinis) blood ${ }^{[23]}$ showed that the difference doses had a significant effect $(P$ $<0.05)$ on the growth rate and population density in Infusoria. The higher dose of mackerel tuna blood gave the higher the growth of infusoria. Based on the research, a good growth rate and population were found in treatment with dose blood of $15 \mathrm{ml} / 1$. The types of infusoria that used were Paramecium sp., Euplotes sp., Stentor sp., Euglena sp., and Oxytricha sp. The dominant type of infurosia was Paramecium sp. 


\section{The role-play of high lipid contents for live feeds enrichment}

Lipids have essential roles in the physiological and biological functions of living organisms ${ }^{[24]}$. Marine and freshwater fish require PUFA in their daily feed, especially during the gastrula stage of fish embryo development when lipids are the main energy source ${ }^{[25]}$. One of source with high content of PUFA is fish oil and other fat sources.

Based on research ${ }^{[26]}$ regarding the effect of giving Daphnia sp. enriched with different fat sources on the survival and growth of tilapia larvae. The proximate and fatty acid composition of Daphnia sp. after being treated showed an increase in lipid content but a decrease in protein content. The highest saturated fatty acid content was found in the treatment of corn oil, namely $17.06 \%$. In addition, research conducted regarding the enrichment effect of Artemia sp. with a combination of soybean oil and salmon oil [27] showed a significant differences between treatments $(P<0.05)$ for absolute growth in mud crab larvae with dose of salmon fish oil $75 \%$, soybean oil $25 \%$ and egg yolk 0.6 .

Recently, not only lipid-enriched used in live feeds culture, but also the source of high HUFA and high protein contents are being used to increase the protein for live feeds culture. The research conducted using bio floc ${ }^{[19]}$, showed there is an increase in crude protein, crude lipid, and crude fiber after being enriched. The highest value was obtained with dose of $20 \mathrm{ml} / \mathrm{l}$ bio floc. In some case, additional nutrition for live feeds culture using lipid enrichment can increase the protein level. The various dose of enrichment can affect its nutritional value, such as higher dose caused higher level of protein (Table 2).

Table 2: The proximate analysis (\%) of live feeds enriched with various sources and doses

\begin{tabular}{|c|c|c|c|c|c|c|c|c|c|}
\hline \multirow{2}{*}{ Animal Species } & \multirow[b]{2}{*}{ Doses } & \multicolumn{6}{|c|}{ Proximate analysis (\%) } & \multirow{2}{*}{$\begin{array}{c}\text { Source of } \\
\text { enrichment }\end{array}$} & \multirow{2}{*}{ References } \\
\hline & & Crude Lipid & Carbohydrate & Crude Fiber & Ash & Crude Protein & Moisture & & \\
\hline \multirow{4}{*}{ Moina sp. } & Without enrichment & 0.16 & 1.75 & 0.16 & 1.75 & 2.51 & 93.65 & \multirow{4}{*}{ Fish meal } & \multirow{4}{*}{ [11] } \\
\hline & $1 \mathrm{gr} / 1$ & 0.28 & 2.13 & 0.28 & 1.46 & 3.14 & 92.68 & & \\
\hline & $2 \mathrm{gr} / \mathrm{l}$ & 0.42 & 2.75 & 0.42 & 1.37 & 4.38 & 90.63 & & \\
\hline & $3 \mathrm{gr} / 1$ & 0.77 & 1.67 & 0.77 & 1.23 & 5.07 & 90.46 & & \\
\hline \multirow{4}{*}{ Artemia sp. } & Without enrichment & 1.76 & 64.15 & 2.3 & 2.25 & 24.04 & 5.50 & \multirow{4}{*}{ Biofloc } & \multirow{4}{*}{ [19] } \\
\hline & $10 \mathrm{ml} / \mathrm{l}$ & 3.31 & 50.1 & 4.13 & 3.83 & 31.59 & 7.04 & & \\
\hline & $20 \mathrm{ml} / \mathrm{l}$ & 6.03 & 15.99 & 6.53 & 7.43 & 53.6 & 10.42 & & \\
\hline & $30 \mathrm{ml} / \mathrm{l}$ & 9.21 & 11.57 & 7.58 & 7.82 & 54.41 & 9.4 & & \\
\hline \multirow{3}{*}{ Daphnia sp. } & $3 \mathrm{gr} / \mathrm{l}$ & 0.92 & - & 0.5 & 0.47 & 3.66 & 94.25 & \multirow{3}{*}{$\begin{array}{c}\text { Spirullina } \\
\text { platensis } \\
\text { meal }\end{array}$} & \multirow{3}{*}{ [12] } \\
\hline & $5 \mathrm{gr} / \mathrm{l}$ & 1.01 & - & 0.64 & 0.17 & 4.19 & 93.91 & & \\
\hline & $7 \mathrm{gr} / \mathrm{l}$ & 0.81 & - & 0.59 & 0.18 & 5.4 & 92.97 & & \\
\hline \multirow{3}{*}{ Daphnia sp. } & - & 80.93 & - & - & - & 10.55 & 87.67 & Fish oil & \multirow{3}{*}{ [26] } \\
\hline & - & 80.85 & - & - & - & 12.83 & 87.5 & Corn oil & \\
\hline & - & 81.12 & - & - & - & 10.01 & 82.25 & Palm oil & \\
\hline
\end{tabular}

\section{Major limits in live feeds culture}

Based on several considerations, live feed remains the most practical use for larva culture in many species. However, to fix the suitable quantities of live feeds at the right times in intensive larva culture systems and make it sustain are not easy. Several factors affect the live feeds production, such as cost of production, especially in smaller hatcheries because mostly the live feed reared in hatchery. The major problems are the way in getting pure strain, lack of infrastructure facility such as controlled environmental condition and its maintenance, etc. became an obstacle in sustainable live feeds culture. Besides that, live feed also perform as a carrier of diseases to the larvae of fish and shellfish, therefore, the high maintain is very important during their culture.

The new technology of live feeds enrichment should be more suitable for small-scale farmers and low-cost production. In Artemia culture production, the pure strains became the major concern because it depends on imported cysts. Therefore, many alternative live feeds can be used such as form ciliates (infusoria). Nutritional value of the live feeds needs to be examined for feeding chart in different stage of fish lifespan. For prospective use, study about the sustainability of live feeds is needed.

\section{References}

1. Gusrina, Budidaya Pakan Alami. Sinergi Pustaka Indonesia, Bandung 2010.

2. Maehre HK, Hamre K, Elvevoll EO. Nutrient evalution of rotifers and zooplankton: feed for marine fish larvae. Aquaculture Nutrition 2012, 1-11.
3. Das P, Bhagabati S, Mandal SC, Akhtar MS. Important Live Food Organisms and Their Role in Aquaculture. Frontiers in Aquaculture 2012, 69-86.

4. Dhont J, Dierckens K, Støttrup J, Stappen GV, Wille M, Sorgeloos P. Rotifers, Artemia and Copepods as Live Feeds for Fish Larvae in Aquaculture. Advances in Aquaculture Hatchery Technology 2013, 157-202.

5. Carter CG. Feeding in hatcheries, in Feed and Feeding Practices in Aquaculture Feed and Feeding Practices in Aquaculture 2015.

6. Montagnes DJS, Dower JF, Figueiredo GM. The Protozooplankton-Ichthyoplankton Trophic Link: An Overlooked Aspect of Aquatic Food Webs. Journal of Eukaryotic Microbiology 2010;57(3):223-228.

7. Pratiwy FM, Pratiwi DY. The potentiality of microalgae as a source of DHA and EPA for Aquaculture Feed: A Review. International Journal of Fisheries and Aquatic Studies 2020;8(4):39-41.

8. Alam MJ, Ang KJ, Cheah SH. Weaning of Macrobrachium rosenbergii (de Man) Larvae from Artemia to Moina micrura (Kurz). Aquaculture 1993;(112):187-194.

9. He ZH, Qin JG, Wang Y, Jiang H, Wen Z. Biology of Moina mongolia (Moinidae, Cladocera) and perspective as live food for marine fish larvae: review. Hydrobiologia 2001;(457):25-37.

10. Loh JY, Ong HKA, Yii SH, Smith TJ, Lock MW, Khoo G. Higly Unsaturated Fatty Acid (HUFA) Retention in the Freshwater Cladoceran, Moina macrocopa, Enriched with Lipid Emulsions. The Israeli Journal of 
Aquaculture-Bamidgeh 2012, 1-9.

11. Prastiwi W, Santoso L, Maharani HW. Pemberian Moina sp. yang Diperkaya Tepung Ikan untuk Meningkatkan Kelangsungan Hidup dan Pertumbuhan Larva Ikan Lele (Clarias sp.). e-Jurnal Rekayasa dan Teknologi Budidaya Perairan 2016;5:575-580.

12. Rahma S, Aryani N, Sukendi. Pengkayaan Kutu Air Menggunakan Tepung Spirullina platensis dengan Dosis Berbeda Terhadap Pertumbuhan dan Kelulushidupan Larva Ikan Mas Koki (Carasius auratus). Fakultas Perikanan dan Kelautan Universitas Riau 2018, 1-9.

13. Koven WM, Tandler A, Kissil GW, Sklan D, Friezlander $\mathrm{O}$, Harel M. The effect of dietary (n-3) polyunsaturated fatty acids on growth, survival and swim bladder development in Sparus aurata larvae. Aquaculture 1990;(91):131-141.

14. Takeuchi T, Watanabe $T$. Effect of various polyunsaturated fatty acids on growth and fatty acid composition of Rainbow trout, Cohu Salmon and Chum Salmon. Bulletin of the Japanese society of scientific fisheries 1982;(41):1745-1752.

15. Akbary P, Hosseini SA, Imanpoor MR. Enrichment of Artemia nauplii with essential fatty acids and vitamin C: effect on rainbow trout (Oncorhynchus mykiss) larvae performance Iranian Journal of Fisheries Sciences 2011;10(4):557-569.

16. Bengtson DA, Leger P, Sorgeloos P. Use of Artemia as a food source for aquaculture In: R.A.Broune, P.Sorgeloos, and C.N.A.Trotman (editions), Artemia Biology. CRC Press, Boca Raton, FL 1991, 255-280

17. Viciano E, Monroig Ó, Salvador A, Amat J, Fiszman S, Navarro JC. Enriching Artemia nauplii with a high DHAcontaining lipid emulsion: search for an optimal protocol. Aquaculture Research 2015;46:1066-1077.

18. Immanuel G, Palavesam A, Petermarian M. Effects of Feeding Lipid Enriched Artemia nauplii on Survival, Growth, Fatty Acids and Stress Resistance of Postlarvae Penaeus indicus. Asian Fisheries Science 2001;14:377388.

19. Supono, Yanti AN, Pertiwi AP, Tarsim, Wardiyanto. The Effect of Nauplii Artemia sp. Enriched with Biofloc on the Performance of Penaeus monodon and Penaeus vannamei Post-Larvae. Aceh Journal of Animal Science 2020;5:81-86.

20. Purba CY. Performa Pertumbuhan, Kelulushidupan, dan Kandungan Nutrisi Larva Udang Vanamei (Litopenaeus vannamei) Melalui Pemberian Pakan Artemia Produk Lokal yang Diperkaya dengan Sel Diatom. Journal of Aquaculture Management and Technology 2012;1:102115.

21. Bertrand J, Caumette $\mathrm{P}$, Lebaron $\mathrm{P}$, Matheron $\mathrm{P}$, Normand P, Simengando T. Environtmental Microbiology: Fundamentals and Applications: Microbial Ecology. Springer 2015.

22. Mukai Y, Sani MZ, Noor M, Kadowaki S. Effective Method to Culture Infusoria, A Highly Potential Starter Feed for Marine Finfish Larvae. International Journal of Fisheries and Aquatic Studies 2016;4(3):124-127.

23. Elmi D, Abdullah, Muhammadar, Nurfadillah. The Effect of Blood Tuna Fish (Euthynnus Affinis) with Different Doses on the Growth Rate and Population Density of Infusoria. Jurnal Ilmiah Mahasiswa Kelautan dan Perikanan Unsyiah 2018;3:33-38.

24. Sargent JR, Bell JG, McEvoy LA, Tocher DR, Estevez
A. Recent developments in the essential fatty acid nutrition of fish. Aquaculture 1999a;(177):191-199.

25. Vetter RD, Houdson RE, Arnold C. Energy metabolism in a rapidly developing marine fish egg, the red drum Sciaenops ocellata. Can J Fish Aquat. Sci 1983;40:627634.

26. Mokoginta I, Jusadi D, Pelawi TL. The Effect of Enriched Daphnia sp. with Different Source of Oil on the Survival Rate and the Growth of Oreochromis niloticus Larvae. Jurnal Akuakultur Indonesia 2003;2:7-11.

27. Khasanah NR, Rahardja BS, Cahyoko Y. Effect of Different Density on the Rate of Mangrove Crab (Scylla Paramamosain) Molting Mass-Reared in Cage. Journal of Marine and Coastal Science 2012;1:125-139. 